\title{
МЕТОКСИФЕНИЛПРОИЗВОДНЫЕ ИМИДАЗОЛИНОВ КАК НИЗКОМОЛЕКУЛЯРНЫЕ АКТИВАТОРЫ Р53
}

\author{
Д.Р. Базанов ${ }^{1}$, Н.В. Первушин ${ }^{2}$, Е.В. Савин ${ }^{2}$, Г.С. Копеина², Н.А. Лозинская' \\ ${ }^{1}$ Химический факультет, МГУ им. М.В. Ломоносова, 119991, РФ, Москва, Ленинские горы, 1. \\ 2Факультет фундаментальной медицины, МГУ им. М.В. Ломоносова, \\ 119991, РФ, Москва, Ленинские горы, 1.
}

DOI: 10.19163/MedChemRussia2021-2021-336

E-mail:daniil_bazanov@mai.ru

На основании фармакофорных моделей действующих ингибиторов взаимодействия $\mathrm{p} 53 / \mathrm{mdm} 2(\mathrm{X})$ - нутлинов нами предложены новые структуры молекул на основе цис-имидазолинового ядра с алкоксифенил-заместителями. Показан оптимальный путь синтеза 2,4,5-трис(алкоксифенил)имидазолинов (серия 2 [1]), а также проведена модификация по атомам азота. В качестве линкеров опробованы диамидная (серия 3а - более 25 примеров) и сульфурильная (серия 3b - более 10 примеров) группы. Показана способность полученных соединений увеличивать уровень р53 в сравнении с контролем до 7 раз (нутлин -10-12 раз).

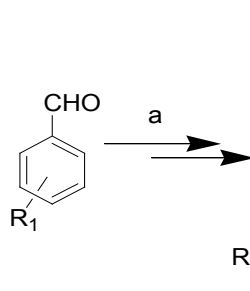

1

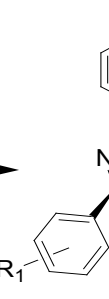

2

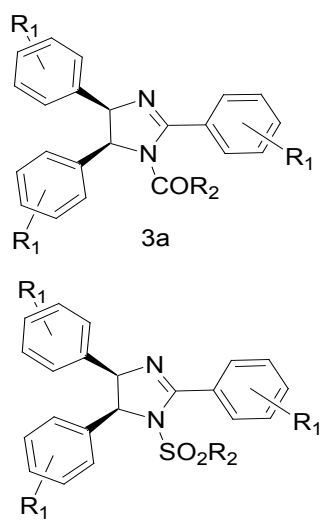

$3 b$

a: $\mathrm{NH}^{3}$ (ТГФ, 24 часа), затем tBuOK (ТГФ, 2 мин.); b: трифосген, затем вторичный амин (CH2Cl2, 30 мин); с: сульфуриламид вторичного амина $\left(\mathrm{CH}_{2} \mathrm{Cl}_{2}\right.$, 24 часа). $\mathrm{R}_{1}=\mathrm{OMe}, \mathrm{OEt}, \mathrm{Me}, \mathrm{F}, \mathrm{Cl}, \mathrm{Br} ; \mathrm{R}_{2}=\mathrm{N}(\mathrm{Et})_{2}$, пирролидин, пиперидин, морфолин, 4-метилпиперидин, гексаметиленимин, тозил.

\section{Литература}

[1] Bazanov Daniil R., Pervushin Nikolay V., Savitskaya Victoria Yu, Anikina Lada V., Proskurnina Marina V., Lozinskaya Natalia A., Kopeina Gelina S., Bioorganic and Medicinal Chemistry Letters. 2019, том 29, № 16, c. 2364-2368, DOI 10.1016/j.bmcl.2019.06.007. 